\title{
Meat production in West African Dwarf goats
}

\section{G. Montsma}

Department of Tropical Animal Production, Agricultural University, P.O. Box 338,6700 AH Wageningen, Netherlands

Key words: dwarf goats, feed intake, feed selection, energy requirements, growth rate, fertility, meat production

\begin{abstract}
Research on improvement of meat production of the West African Dwarf goat (WADG), in combination with the utilization of low-quality feeds is described. The WADG appears to be a suitable meat animal under low but also under high levels of feeding and management. Under intensive management daily gains of $80 \mathrm{~g}$ were obtained, i.e. 0.3-0.4\% of mature weight, and 2.56 kids per doe per year were produced. On roughage diets only, daily gains of $43 \mathrm{~g}$ were reached. By heavy feed selection the goat is able to ingest a better-than-average ration, if excess feed is offered. Studies on intake regulation and on optimal ration formulation are in progress.
\end{abstract}

\section{Introduction}

The Department of Tropical Animal Production is one of several tropics-oriented departments of the Agricultural University. It was founded in 1947 and initially largely concerned with problems in connection with the introduction of high-yielding dairy cattle into the (sub)tropics. Gradually, however, the idea grew that research on tropical livestock might be of more relevance to farmers in developing countries. In addition, interest gradually switched from genotype to phenotype, and factors like nutrition, climate and management became more important. One of the major problems in this field is the utilization of low-quality feeds in the tropics.

Further, it was realized that goats, and more specifically meat goats, were a neglected subject of research and therefore the West African Dwarf goat (WADG) was chosen as experimental animal. Other reasons for the choice of this animal were: its availability in the Netherlands (as a pet animal), the importance of small ruminants for small farmers in humid Africa, its tolerance to trypanosomiasis, its small size and the possibility it offered for co-operation with research institutions in the tropics. The latter aspect indeed led to a co-operation between the Department of Animal Science of the University of Ife, Nigeria, the International Livestock Centre for Africa (ILCA) at Addis Ababa and our department. At Ife and at our department flocks of approximately 200 dwarf goats are kept. 
Major points of this co-operation are the common interest in research, the exchange of staff and students and the complementarity of facilities. The contract became effective in 1981 and is intended to last to the end of 1988.

\section{Dwarf goats in West Africa}

According to Jahnke (1982) the small-ruminant population of humid Africa amounts to approximately 20 million head, $60 \%$ of which are goats. Though at the end of its life the goat provides meat, its major function during life is to act as savings account, apart from its social and cultural role. These may be reasons that ownership is widespread. According to an ILCA survey (Okali \& Upton, 1985) in villages in south-west Nigeria up to $75 \%$ of the households own these animals. In the same survey, they found that out of 90 goat purchases, 17 were for breeding, 13 for festival and 60 for ceremonial purposes. Many dwarf goats are kept free roaming, but in more densely populated areas they are confined or tethered, at least during the cropping season.

Mature weight of these dwarf goats is approximately $18-20 \mathrm{~kg}$ in the village, but under favourable conditions it may reach $25 \mathrm{~kg}$. Growth rate depends on feed availability, but is considered to be low under village conditions. A post-weaning daily gain of less than $20 \mathrm{~g}$ is mentioned by Mack (1983). Oestrus is not affected by daylength, but seasonality of oestrus does occur as a direct result of variation in feed supply and probably high temperatures. Kid mortality may reach $50 \%$ in the villages (Mack, 1983) leading to a net annual increase of less than one kid per doe.

\section{Research}

Since little was known about these dwarf goats, both in Wageningen and Ife, work started with the formation of experimental flocks and collection of information on production parameters. In both places the animals had to be purchased from a large number of farms and in Nigeria also from markets. In Wageningen a total of 75 animals was purchased in two batches. But in Ife, due to a much higher disease incidence, many small groups of 10-12 animals had to be acquired which could join the main flock only after careful quarantine.

Thus both flocks consisted of largely unrelated animals. Up till now selection within the flocks has been avoided as far as possible. Reasons for this are that we are more interested in environmental effects on production and therefore try to keep the animal factor constant, and also that we have not yet defined a clear selection aim. Routine observations mainly concern daily weight gain, health and mortality and reproductive parameters. Specific experiments mainly concern effects of nutrition and climate on production.

\section{Animal parameters}

Reproduction. A major asset of these dwarf goats is their high reproductive rate. If sufficient feed is available they will breed throughout the year and produce large lit- 
Table 1. Reproductive performance of WADG under three different conditions. Data for Wageningen are over 7 years (Hofs et al., 1985), for Ife over 4 years (Bosman, 1986), for village: survey data from Mack (1983). Kid mortality at Ife declined from $48 \%$ in $1982 / 3$ to $28 \%$ in $1984 / 5$.

\begin{tabular}{llll}
\hline & Wageningen & Ife University & Village \\
Kidding rate (\%) & 81 & 86 & 85 \\
Litter size at birth & 1.83 & 1.70 & 1.5 \\
$\quad$ at weaning & 1.66 & 1.12 & 1.0 \\
Kidding interval (d) & 193 & 260 & 259 \\
Weaned kids per doe per year & 2.56 & 1.51 & 1.41 \\
\hline
\end{tabular}

ters. Under village conditions in the tropics mortality is, however, also high and therefore a high reproductive rate probably has a high survival value. Disease incidence is much lower in Wageningen and since the high reproductive rate is still present, this leads to a high multiplication rate, as illustrated in Table 1.

Growth. Daily weight gain shows a wide variation under favourable conditions. Average pre-weaning gain in Wageningen is $85 \mathrm{~g} \mathrm{~d}^{-1}$ (range 10-148 $\mathrm{g} \mathrm{d}^{-1}$ ). Post-weaning gain is lower, namely $50 \mathrm{~g} \mathrm{~d}^{-1}\left(15-90 \mathrm{~g} \mathrm{~d}^{-1}\right)$, strongly depending on feed quality and intake. Data for the Ife flock show lower values, namely $47 \mathrm{~g} \mathrm{~d}^{-1}$ pre-weaning and $26 \mathrm{~g} \mathrm{~d}^{-1}$ post-weaning gain. Major reasons are that the flock at Ife was formed since 1982 only, that most of the original animals had to be bought on the market and were not of outstanding quality, feeding was less intensive, disease was more frequent and the number of first parities higher. In feeding trials in Ife gains of $60 \mathrm{~g}$ $\mathrm{d}^{-1}$ on high concentrate rations and $43 \mathrm{~g} \mathrm{~d}^{-1}$ on good-quality roughage were obtained (Ademosun et al., 1985b). Similar levels of production can be expected for the main flock in future. Results for the Wageningen flock indicate that in a favourable environment these dwarf goats have a high meat production potential and this warrants study of the environmental limitations to higher yields. One should not conclude from these data that dwarf goats have to be kept under very intensive levels of feeding and management. That depends on the output:input ratio in the pertaining farming systems in Africa and particularly on the quality and quantity of the feed available.

Productivity. Growth and reproduction rates can be combined in a productivity index (Turner \& Young, 1969). Space does not permit to go into detail, but the results, expressed as kg of weaned kid per doe and per year, are for the Wageningen flock $21.2 \mathrm{~kg}$, for the Ife flock $9.6 \mathrm{~kg}$ (Bosman, 1986) and for a village flock in southwest Nigeria $5.5 \mathrm{~kg}$ (Mack, 1983). Reasons for the lower value for the Ife flock are similar to those mentioned under growth. In addition, mortality is higher. Parameters which are strongly affected by environment, like daily gain and mortality, appear to have more effect on productivity than factors like litter size and birthweight, which are less affected by environment. 


\section{Nutrition}

Attention is paid to two aspects, firstly, development of feeding standards in terms of energy and protein requirements and secondly, improvement of feed intake.

Feeding standards. Feeding standards, expressed in less or more precise terms, have been in use for a long time. Their use presumes, however, that the requirements of the animal can indeed be met, that is, that ingredients for the ration are available. In many tropical countries the situation is often the reverse: quantity and especially quality of the feed are restricted, the animal is the dependent variable and feed intake becomes a major limiting factor.

Since data in the literature on energy and nitrogen requirements of goats show a very large variation it was deemed desirable to collect more information. From a first set of data the following relationship between intake of digestible organic matter (IDOM, $\left.\mathrm{g} \mathrm{d}^{-1}\right)$, body weight $(\mathrm{W}, \mathrm{kg})$ and gain $\left(\mathrm{G}, \mathrm{g} \mathrm{d}^{-1}\right)$ was derived: IDOM = $26 \mathrm{~W}^{0.75}+2.41 \mathrm{G}$ (Zemmelink et al., 1985). The resulting estimate for maintenance requirements ( $410 \mathrm{~kJ} \mathrm{ME}$ (metabolizable energy) $\mathrm{W}^{-0.75}$ ) of confined goats is close to the estimate of NRC (1981) (424 kJ ME W $\left.{ }^{-0.75}\right)$. On the other hand, our present requirement for gain $\left(38.0 \mathrm{~kJ} \mathrm{ME} \mathrm{g}^{-1}\right)$ is approximately $25 \%$ higher than the requirement quoted by NRC $\left(30.3 \mathrm{~kJ} \mathrm{ME} \mathrm{g}^{-1}\right)$. The latter value is the mean of three widely divergent estimates quoted in the original literature $(42.6,26.9$ and $21.5 \mathrm{~kJ}$ $\mathrm{ME} \mathrm{g}^{-1}$ ), which may not all be reliable. On the other hand, energy requirements per $\mathrm{g}$ of gain may vary with the composition of gain. Moreover, estimated values may also be affected by the method of data analysis: if G instead of IDOM were chosen as the independent variable in regression analysis of our data, the requirement would be estimated at $44.4 \mathrm{~kJ} \mathrm{ME} \mathrm{g}^{-1}$. There is considerable disagreement in the literature as to which procedure should be followed.

The value of $38.0 \mathrm{~kJ} \mathrm{ME} \mathrm{g}^{-1}$ falls within the values obtained by similar procedures

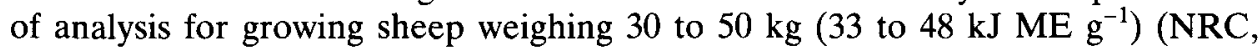
1975).

Our data on protein requirements suggest that also in this respect these dwarf goats do not perform differently from sheep. In West Africa, dwarf goats and dwarf sheep are often kept together. On the basis of our present knowledge of nutrient requirements a preference in this respect for sheep or goats cannot be expressed.

Feed intake and digestion. It is often assumed that goats have a high digestive capacity, which enables them to live on low-quality feeds (e.g. Louca et al., 1982). This is, however, not borne out by experimental evidence. In almost 200 experiments in the literature comparing digestive capacity in sheep and goats, regression analysis shows no difference in digestive capacity between the two species. From our own experiments it appears that feed intake per $\mathrm{W}^{0.75}$ and digestive capacity are the same for Dutch Texel sheep of $70 \mathrm{~kg}$ and dwarf goats of $20 \mathrm{~kg}$ live weight (B. Tolkamp, pers. comm.). Van Soest (1982) also suggested that the conclusion that goats digest feed better than sheep and cattle do is merely the result of the goat's capacity to select the better part of the ration offered. 
A major question is how to utilize low-quality feeds. The extremes are: allow no feed selection and allow maximum feed selection. The first leads to very poor performance and the need to use large numbers of animals, if all the feed has to be used. The second leads to a much better performance but utilizes only a small proportion of the feed. In between the two we try to enhance feed intake and to study factors which affect this parameter. It is often assumed that feed intake from roughage is regulated by the capacity of the rumen to handle undigested feed. We have reason to believe, however, that metabolic intake regulation may play a role also in roughage feeding and that the ratio of resorbed nutrients (e.g. protein:energy) might have an effect on feed intake. Experimental evidence is, however, not clear.

The flock of Ife was initially kept grazing on pasture. It soon appeared that in this way the animals could not even maintain body weight. Feed intake was low and disease incidence high. Switching to zero-grazing on grass improved the health situation but daily gain was unsatisfactory.

The importance of feed selection became clear already in the first experiment on feed intake (Table 2). It appeared that feed intake increased both in quantity and in quality if excessive amounts were offered. Intake of ME and DCP was, however, still too low, even for maintenance. If we assume that the goat is a selective browser, then confinement means a severe restriction in the number of feed sources available to the animal. If confinement becomes necessary, for instance for health reasons or to prevent crop damage, then a major nutritional problem will be to develop rations which:

- enable a high production level, c.q. feed intake

- do not require excessive feed selection

- are available on a year-round basis

- do not require a large number of ingredients

- are economically justified.

Grass in general does not comply with these conditions, if only because feed intake is low and both quantity and quality are subject to large seasonal variation. Therefore supplementation with (bushy) legumes, Leucaena leucocephala and Gliricidia sepium, was tried. Some of the results are shown in Table 3. In this experiment an increase in Gliricidia DM intake of $5 \mathrm{~g}$ corresponded with a decrease of $1 \mathrm{~g}$ of grass DM intake only. Total intake of digestible dry matter (DDM) reached $37.9 \mathrm{~g}$

Table 2. Effect of level of stargrass hay (Cynodon nlemfuensis), offered to West African Dwarf goats, on voluntary intake, selective consumption and digestibility $(n=3 \times 3)$. (From Ademosun et al., 1985a.)

\begin{tabular}{llllllll}
\hline $\begin{array}{l}\text { DM offered } \\
\left(\mathrm{g} \mathrm{W}^{-0.75}\right.\end{array}$ & $\begin{array}{l}\text { Leaf in diet }(\%) \\
\left.\mathrm{d}^{-1}\right)\end{array}$ & offered & selected & $\begin{array}{l}\text { DM intake } \\
\left(\mathrm{g} \mathrm{W}^{-0.75}\right. \\
\left.\mathrm{d}^{-1}\right)\end{array}$ & $\begin{array}{l}\text { Digesti- } \\
\text { bility } \\
(\%)\end{array}$ & $\begin{array}{l}\text { DDM intake } \\
\left(\mathrm{g} \mathrm{W}^{-0.75}\right. \\
\left.\mathrm{d}^{-1}\right)\end{array}$ & $\frac{\text { CP in diet }(\%)}{\text { offered }}$ \\
44 & 43.2 & 54.5 & 32.2 & 40.1 & 13.0 & 4.3 & 4.8 \\
88 & 43.2 & 75.2 & 40.6 & 43.2 & 17.5 & 4.3 & 5.7 \\
131 & 43.2 & 86.7 & 39.9 & 46.4 & 18.5 & 4.3 & 6.2 \\
\hline
\end{tabular}




\section{G. MONTSMA}

Table 3. Effect of level of Gliricidia sepium in combination with Panicum maximum hay fed to West African Dwarf goats on voluntary intake and digestibility $(n=4 \times 6)$. (From Ademosun et al., 1985b.)

\begin{tabular}{|c|c|c|c|c|c|c|}
\hline \multicolumn{2}{|c|}{ DM offered $\left(\mathrm{g} \mathrm{W}^{-0.75} \mathrm{~d}^{-1}\right)$} & \multicolumn{3}{|c|}{ DM intake $\left(\mathrm{g} \mathrm{W}^{-0.75} \mathrm{~d}^{-1}\right)$} & \multirow{2}{*}{$\begin{array}{l}\text { Digestibility } \\
(\%)\end{array}$} & \multirow{2}{*}{$\begin{array}{l}\text { DDM intake } \\
\left(\mathrm{g} \mathrm{W}^{-0.75} \mathrm{~d}^{-1}\right)\end{array}$} \\
\hline P. maximum & G. sepium & $P$. maximum & G. sepium & total & & \\
\hline 73.5 & 0 & 43.1 & 0 & 43.1 & 46.0 & 19.8 \\
\hline 73.5 & 10.8 & 39.8 & 10.8 & 50.6 & 47.7 & 24.5 \\
\hline 73.5 & 21.3 & 38.1 & 21.3 & 59.4 & 51.1 & 30.3 \\
\hline 73.5 & 31.8 & 37.2 & 31.8 & 69.0 & 54.9 & 37.9 \\
\hline
\end{tabular}

$\mathrm{W}^{-0.75} \mathrm{~d}^{-1}$, i.e. approximately 1.4 times maintenance, leading to a daily gain of approximately $30 \mathrm{~g}$. Further work along this line is in progress.

It was observed that the goats eat both leaves and bark of the legumes, with little preference for either of them.

\section{Health}

Space permits only a few remarks on this subject. Firstly, it appears likely that a prerequisite for investment is vaccination against PPR ('peste des petits ruminants'). Secondly, intestinal parasites can be kept under control by using split-bamboo slatted floors. Thirdly, research aims at reaching a health package for the small farmer that is within his financial reach.

\section{Climate and housing}

Since these dwarf goats developed in the humid tropics it was considered worthwhile to measure their reactions to hot and cold climates by means of climate-respiration chambers. Results indicate that the animals react more or less 'according to the book', both in hot (Luiting et al., 1985) and in cold climates (G. Montsma \& P. Hofs, unpublished results, 1984). When kept at $35^{\circ} \mathrm{C}$ and $60 \% \mathrm{RH}$, their intake of concentrates $\left(30 \mathrm{~g} \mathrm{~W}^{-0.75} \mathrm{~d}^{-1}\right)$ did not decline, but intake of roughage decreased by $40 \%$ compared with $20{ }^{\circ} \mathrm{C}$ and $60 \% \mathrm{RH}$. This lower feed intake, together with a tenfold increase in respiratory rate and a $20 \%$ decline in heat production, caused an increase in rectal temperature of only $0.8^{\circ} \mathrm{C}$ (Montsma et al., 1985). Results suggest that in West Africa in the hot-humid pre-rainy season feed intake may decline and this may lead to lower fertility. Since goats strongly dislike rain, effects of artificial rain are studied presently. In Ife two low-cost stables have been made to study the minimum housing requirements for these goats.

\section{Discussion and future research}

Most of the ideas behind this work have been mentioned in the previous sections. The basic question is, how to use this goat to convert available feeds into meat. To answer this question, many sub-questions have to be asked and answered. Some of 
these are dealt with in this joint project and it is hoped that others will join in the effort.

Results so far suggest that this dwarf goat can survive under unfavourable conditions, but that it is also capable of quite satisfactory levels of weight gain and fertility under favourable conditions. As little or no direct selection on weight gain was applied in the past, this parameter shows a large variation, a fair proportion of which may be genetic. Selection for higher growth rates should, however, take the prevailing feed situation into account.

A major question is how to utilize low-quality feeds. As feed intake from lowquality feeds is the first limiting factor, studies on regulators of this parameter have been started, together with trials to find combinations of ingredients that will be consumed in sufficient quantities. In these rations concentrates should not be excluded a priori as it is well known that by a combination of high- and low-quality feeds more of the low-quality feed can be utilized. The question whether this combination used for ruminants will lead to better results, compared with the separate use of concentrates for non-ruminants plus only roughage for ruminants, is first of all a matter of economics within the prevailing farming system. These economic factors will be studied in Nigeria under both experimental and farmer's conditions. This should also provide information on how goats may fit in a system of alley cropping.

The large variation in growth rate of WADG offers a possibility to study interactions between performance and feed supply. Also behavioural aspects, such as the strong ranking order and ruminating behaviour, need further investigation, also in respect of scale differences between species.

Health aspects, especially those in connection with the confinement of animals in a relatively small space, need further attention. It would be wasteful if a large part of the precious $\mathrm{ME}$ for production would have to be used to combat the stress of diseases like Caseous lymphadenitis and mange.

Finally, it is suggested that the dwarf goat, as a small ruminant, offers certain advantages as a cheap model experimental animal. Its inquisitive nature may, however, be a disadvantage in experimental work.

\section{Acknowledgements}

This paper has one author, but it is clear that most of the work was performed by the other members of the team, viz: Prof. Dr A. A. Ademosun, Dr L. B. Smith, Ir H. J. Jansen, Ir H. G. Bosman, Ing. P. Roessen (at Ife) and Dr Ir G. Zemmelink, Ing. P. Hofs, Ing. M. van Houtert and Ir B. Tolkamp (at Wageningen). Only the length of this list prohibits their names being mentioned as co-authors.

\section{References}

Ademosun, A. A., H. J. Jansen \& M. van Houtert, 1985a. Research on goat management at the University of Ife. Proceedings of the Workshop on small ruminant production systems in the humid zone of West Africa (Ibadan, Nigeria).

Ademosun, A. A., H. G. Bosman and P. L. Roessen, 1985b. Nutritional studies with West African 


\section{G. MONTSMA}

Dwarf goats in the humid zone of Nigeria. Seminar on SR production systems in the humid zone of West Africa (ILCA, Addis Abeba).

Bosman, H. G., 1986. Management of the West African Dwarf Goat in the humid tropics. Progress report 7, Dept. of Tropical Animal Production, Agricultural University, Wageningen, Netherlands.

Hofs, P., G. Montsma \& S. Nabuurs, 1985. Growth and reproduction rates of West African Dwarf Goats under high levels of feeding and management. Proceedings of the Workshop on small ruminant production systems in the humid zone of West Africa (Ibadan, Nigeria).

Jahnke, H. E., 1982. Livestock production systems and livestock development in tropical Africa. Kieler Wissenschaftsverlag Vauk, Kiel.

Louca, A., T. Antoniou \& M. Hatzipanayiotou, 1982. Comparative digestibility of feedstuffs by various ruminants, specifically goats. In: Proceedings of the 3rd International Conference on goat production and disease (Tucson, Arizona), p. 122-132.

Luiting, P., G. Montsma, M. W. A. Verstegen, P. Hofs, W. van der Hel \& J. W. Zijlker, 1985. Effects of high ambient temperatures on the metabolism of West African Dwarf Goats. I. International Journal of Biometeorology 29(1): 11-22.

Mack, S. D., 1983. Evaluation of productivities of West African Dwarf sheep and goats in southwest Nigeria. Humid Zone Programme Document 7. ILCA, Iabadan, Nigeria.

Montsma, G., P. Luiting, M. W. A. Verstegen, W. van der Hel, P. Hofs \& J. W. Zijlker, 1985. Effects of high ambient temperatures on the metabolism of West African Dwarf Goats. II. International Journal of Biometeorology 29(1):23-35.

NRC, 1975. Nutrient requirements of sheep. National Academy of Sciences, Washington, DC.

NRC, 1981. Nutrient requirements of goats. National Academy of Sciences, Washington, DC.

Okali, C. \& M. Upton, 1985. The market potential for increased small ruminant production in southwest Nigeria. Proceedings of the Workshop on small ruminant production systems in the humid zone of West Africa (Ibadan, Nigeria).

Tolkamp, B. J., 1985. Regulation of feed intake. Review of literature. Dept. of Tropical Animal Production, Agricultural University, Wageningen, Netherlands.

Turner, H. N. \& S. S. Y. Young, 1969. Quantitative genetics in sheep breeding. Macmillan of Australia, Sydney, $332 \mathrm{pp}$.

Van Soest, P. J., 1982. Nutritional ecology of the ruminant. O and B Books, Corvallis, Oregon.

Zemmelink, G., B. J. Tolkamp \& J. H. Meinderts, 1985. Feed intake and weight gain of West African Dwarf Goats. Proceedings of the Workshop on small ruminant production systems in the humid zone of West Africa (Ibadan, Nigeria). 